\title{
The changing environment and human activities: implications for human health
}

\author{
John Daniel Yiljika ${ }^{1}$, Jonathan Zumunta Danna ${ }^{2}$ \\ ${ }^{1}$ Department of Biology, College of Education, Azare, Bauchi State, Nigeria \\ ${ }^{2}$ Department of Integrated Science, College of Education, Azare, Bauchi State, Nigeria
}

\begin{abstract}
Change in the environment is inevitable and rapid. The cause of the change could be a natural phenomena or life processes. Human activity such as development of agriculture and technology which give rise to widespread industrialization has led to potentially changing environment as a result of pollution culminating in the release of harmful substances such as Agricultural waste, industrial waste, metal scraps, sewage, microbial concentration, oil spills etc. into the soil, water or air. Human environmental intervention as in the construction of dams and diversion of rivers is another cause of change in the environment. Other causes are ozone depletion, Acid rain and acid mine drainage etc. The impact of the changing environment on human health identified in this paper seek to explore the causes of environmental change, effect of human activities on causes of environmental change and effect of changing environment on human health. The findings identified some effects of human activities as outbreaks of infectious diseases leading to human incapacitation and death in severe cases, damage genetic material leading to heritable genetic disorders, malnourishment as a result of wiping out of plants and animal life. Others are skin cancer, reduction of life expectancy etc. some recommendation were made which are Environmental conservation measures, Governments and Nongovernmental organizations educating the citizenry.
\end{abstract}

Keywords: natural phenomena; life processes; change in the environment

\section{INTRODUCTION}

The environment is composed of the components which could be natural or man-made. The components of the environment specifically include: the atmosphere (air), the Hydrosphere (water), the Lithosphere (rocks and soil) and biosphere (Living component). Environment is referred to as the surrounding of an organism. It is composed of all the living things (biotic component) and non-living things (a biotic component) that surround us. Environment has played a key role in the evolution of the biological spectrum by the process of natural selection and elimination. It has influenced and shaped our lives since time immemorial (Kapoor, 2007). The environment provides us with our daily requirement essential for our existence hence the evolution of the earth's environment and life on earth has gone hand in hand. The environment had being undergoing changes both naturally and artificially; this has an immense effect on plant and animal species. According to Myers and Tickell (2001), there have been more changes in the environment in the last 200 years than in the last 2000 years and more changes in the last 20 years than in the last 200 years. The rate 
of species extinction is now well beyond the natural rate, in what is sometimes referred to today as the "biotic holocaust".

Global climate change in particular threatens human health in numerous and profound ways. Large segments of the population will experience more heat waves, altered exposure to infectious disease, and more frequent natural disasters .Most significantly; climatic disruption threatens the adequacy of the core "building blocks" of health for large populations around the globe: sufficient food and nutrition, safe water for drinking and sanitation, fresh air to breathe, and secure homes to live in (Myer, 2009).

Myer, (2009) confirmed the report by united nation Foundation and World watch institute, that human have transformed the Earth's land surface and altered the function of its ecosystems, and we are triggering the rapid loss of both terrestrial and marine life. We are also profoundly changing our planet's climate. It is increasingly apparent that the breadth and depth of the changes we are wreaking are imperiling not only many other species, but the health and wellbeing of our own species as well.

\section{CHANGES IN THE ENVIRONMENT AND CAUSES}

The earth's environment has over the years undergone various transformations due to natural phenomena and human activities. The existence of human and other life on earth as well as occurrence of natural phenomena has made changes in the environment to be an inevitable experience. The change in the environment could be rapid (sudden) or slowly and could come from natural or human sources (Miller and Spoolman , 2008).

It is important to note that any undesirable change in the physical, chemical or the biological properties of the environment is considered environmental pollution. Weekly trust (march, 2014) reported that change in climatic condition have continued to vary in recent times, from droughts in both East and West Africa, floods in India, stormy wind in America to Typhoon haiyan in the Philippines.

Here in Nigeria, News about floods has already begun filtering this February and in some of the unlike areas such as in Edo state and a return of strong harmattan winds around the Federal Capital Territory (FCT) Abuja (Weekly trust, 2014).

The weather is indeed changing and scientists tell us that climate change is the culprit and they refer to a combination of human activities that is said to be negatively impacting on nature thereby forcing it to tilt its balance in terms of how the conditions of the weathering are operating. The weekly trust (march, 2014) reported that currently $97 \%$ of world scientists have agreed that climate change is indeed a threat to human existence as evident in continuous loss of vegetation cover, increase in global warming with its attendant health ties such as industrial activities, Transportation, bush burning and other activities that encourage carbon emission are responsible for a $97 \%$ cause of climate change. Myers (2009) identifies some global land use and climate change drive new patterns of disease exposure through five main mechanisms:

- Changes in the density or presence of disease-related organisms. Changes in temperature, precipitation, nutrient concentrations, and other parameters are often fundamental in defining the range and breeding habitat of vectors, hosts, and pathogens;

- Changes in exposure pathways. Direct human incursions into wildlife habitat (e.g., to establish new settlements or for bush meat hunting), rural-to-urban migration, and the 
movement of non-immune workers into disease-endemic areas can all lead to new exposure pathways.

- Change in the genetics of pathogens. Intensified livestock management can allow pathogens to proliferate and develop genetic modifications more rapidly, affecting both the infectiousness and virulence of disease organisms.

- Changes in the life cycles of pathogens and vectors. Higher air temperatures, for example, are associated with shorter egg-laying cycles, faster development, and increased survivorship among Anopheles mosquitoes, increasing their capacity to spread malaria.

- Changes in species composition. Complex changes in the types of organisms that make up ecological communities can have dramatic impacts on disease exposure by creating conditions and relationships that favor certain pathogens over others.

Infectious diseases that are transmitted by a vector or that have a non-human host or reservoir, such as malaria, dengue fever, schistosomiasis, and Chagas disease, are particularly sensitive to these types of changes. Given that such diseases affect more than half the human population, alterations in their transmission can have significant impacts on global public health.

Individuals that are most likely to feel the impact of climate change are the cattle herders, farmers and those at the coastal areas. Climate change is faceless yet with so powerful impact, it may not be very popular like HIV/AIDS or War, but it is one silent phenomenon that is gradually eating into the fabric of many countries and Nigeria is no exception.

\section{HUMAN ACTIVITIES AS THE CAUSE OF CHANGING ENVIRONMENT}

Ample evidence suggests that human disruption of ecological systems is changing the distribution of infectious disease, leading in many instances to increased transmission. Man made changes in the environment can permanently change the environment.

The conversion of forest land into Agricultural land or pasture land, or release of extra ordinary amounts of carbon(IV) oxide and chlorofluorocarbons (CFC) into the atmosphere are due to human actions. Taylor et.al (2010) reported that human activity such as development of Agriculture and technology which give rise to wide spread industrialization has led to potentially changing environmental pollution. Human environmental intervention as in the construction of dams and diversions of rivers is another cause of change in the environment.

Garg, (2010) Summarized human activities causing environmental in- balance and pollution as: Agriculture, Industrialization, Urbanization, Mining and Transportation. Human activity, through industry, agriculture, energy generation and transport, has released significant amounts of green house gases (GHGs) into the atmosphere since the beginning of the industrial era, and there is concern that this may be inadvertently modifying the global climate through enhancement of the natural greenhouse effect (Beniston, 2000).

Another form of human activity that can cause damage to the environment and life, it is the dumping of Electronic waste popularly known as E-waste into water body and land. Ewaste consists of discarded television sets, cell phones, computers, e-toys and other electronic devices. It is the fastest growing solid waste problem in the United States and in the world. Each year, Americans discard an estimated 155 million cell phones, 250 million personal 
computers, and many more millions of television sets, Ipads, Black berries and other electronic products (Miller and Spoolman, 2008).

Most e-waste ends up in landfills and incinerators. It includes high quality plastics and valuable metals such as Aluminum, Copper, Nickel, Platinum, Silver and Gold. The concentration of copper in e-waste, for instance, is much higher than in currently mined copper ores. E-waste is also a source of toxic and hazardous pollutants including polyvinylchloride (PVC), Brominates flame retardants, lead and mercury, which can contaminate air, surface water, ground water and soil.

According to 2005 report by the Based Action Network contained in Miller and Spoolman (2008), about 50-80 \% of U.S. e-waste is shipped to china, India, Pakistan, Nigeria and other developing countries where labor is cheap and environment regulations are weak.

Other causes of environmental change due to human activities include ozone layer depletion, acid rain and acid mine drainage from highly industrialized environments. Changes in temperature, precipitation, nutrient concentrations, and other parameters are often fundamental in defining the range and breeding habitat of vectors, hosts, and pathogens;

\section{EFFECT OF ENVIRONMENTAL CHANGE ON HUMAN HEALTH}

The changing environment has tremendous effects to human health both directly and indirect.

\section{1. Direct effects of environment change on human health}

Chemical compounds impose severe adverse effects on the environment. Also, they lead to a wide variety of adverse health problem like cancer, asthma, hearing loss and to ecological deterioration (Nwafor, 2006). The deterioration of hearing, hardening of the artery (Arteriosclerosis) is caused by noise pollution. Lead dust leads to lead poisoning and injury to the Nervous system.

According to Ababio, (2011) Smoke, Soot and dust emitted by industrial processes and the burning of coal and fire wood damage the respiratory system especially the lungs. Carbon (II) oxide from incomplete combustion of coal, and fuel from exhaust of vehicles reacts with hemoglobin in red blood cells and reduces the ability of blood to transport oxygen to body cells and tissues, chronic exposure can trigger heart attack and aggravate lung diseases such as Asthma and Emphysema. At high levels carbon(II) oxide causes headache, nausea, drowsiness, mental impairment, collapse, coma and death.

Ozone $\left(\mathrm{O}_{3}\right)$ a colorless and highly reactive gas is a major component of photochemical smog. It can cause coughing and breathing problems, aggravate lung and heart diseases, reduce resistance to colds and pneumonia and irritate the eyes, nose and throat. It also damage genetic material leading to heritable genetic disorders.

Keatinge, Donaldson, Cordioli, Martinelli and Kunst (2000) reported that heat waves, particularly in large urban areas, are associated with episodes of strong pollution often linked to the formation of tropospheric ozone, a gas that is formed by chemical transformation of nitrogen oxides and other "precursor" gases released during the combustion of fossil fuels. Ozone is a highly corrosive gas that can irritate or damage lung tissues in addition to provoking eye irritation. 
Narayanan (2009) reasoned that inhalation of silica and asbestos dust lead to fibrotic lesion, fibrosis, asbestosis or abnormal accumulation of connective tissues. Silicosis is a chronic disease of the lungs which is a type of pneumoconiosis.

\section{2. Indirect effects of environment change on human health}

Aromatic hydrocarbons are extremely hazardous and dangerous to human health. They are accumulated in shrimps and fish drinking water contaminated with them. Eating fish, shrimps and other animals from this water will lead to bio accumulation of the chemicals in human body which cause cancer and mutation.

Increased level of carbon(IV) oxide causes green house effect and subsequent global warming making life uncomfortable. Dumping of Agricultural waste, industrial waste, sewage, refuse, oil spills etc contaminate water bodies. Eutrophication favored aquatic plant growth leading to algal bloom as well as increased concentration of microbes that through their metabolic processes deplete the dissolved oxygen in water.

This causes suffocation of aquatic life and consumption of aquatic animals lead to accumulation of toxic metals in human body.

Chlorofluorocarbons (CFCs) are gaseous chemicals that destroy the ozone layer and form big hole. When the ozone layer is depleted more ultraviolet rays reach the earth surface and cause:

(i) Skin cancer, cataracts of the eyes and sunburns in human beings.

(ii) Beneficial micro organisms are killed.

(iii) Too much ultraviolet rays, destroys chloroplast thereby hindering photosynthesis. This indirectly affects human's health by causing starvation and malnourishment.

Acid mine drainage from mining regions into streams and river blanket the stream bed and wipe out plant and animal life from their environment creating serious implication to human health. Other effects of environmental change to life include outbreak of infectious agents and reduction of life expectancy. Human-caused environmental change adversely affects health through other pathways as well. These include: Water and sanitation. Inadequate access to drinking water, sanitation, and hygiene causes an estimated 1.7 million deaths annually Myers, (2009). As with food, our ability to meet future water needs faces serious constraints, from reduced access to fresh water as a result of climate change, to declining water quality, to rising demand as a result of population growth and economic development.

\section{CONCLUSIONS}

The earth's environmental change is unavoidable as long as human exist upon its face. The changes in the environment are varied and enormous. Human beings in pursuit of food, Education and Comfort have greatly altered the environment through range of activities. These activities include construction of roads, dams, railways and House; establishment of diverse industries; mining; discharge of domestic and Agricultural wastes etc. the human activities either directly results in the immediate change and destruction of ecosystem or release of harmful chemicals, heat, gases and other materials into the environment (air, water and land). 
Health problems such as cancer, heart attack; genetic disorders, respiratory diseases e.g. Asthma, Pneumonia; sicknesses and death from infectious diseases such as cholera, malaria, Dengue fever etc. are direct impacts of the changing environment on human health. Others such as malnutrition, Death of aquatic organisms and bioaccumulation of toxic chemicals are some of the indirect negative effects of the changing environment on human health. These impacts have serious implications in the reduction of life expectancy of humans.

\section{Recommendations}

1. Effort should be intensified on environmental conservation measures by all and sundry.

2. Various Governments and Non-governmental organization to be activity involved in funding of such efforts.

3. Environmental Impact Assessment and Monitoring should be carried out from time to time to assess and monitor increase or decrease pollution levels.

4. Improving social awareness and preparedness, in particular through information on the risks associated with climate change and health, early-warning systems and public education programmes.

\section{References}

[1] Ababio O. Y. (2011). New school chemistry for senior secondary school $\left(6^{\text {th }} \mathrm{Ed}\right)$ Africana First Publishers plc, Onitsha. Pp. 620.

[2] Beniston M. (2000). Environmental Change in Mountains and Uplands. London: Arnold Publishers: and New York: Oxford University Press; p. 172.

[3] Garg S. K. (2010). Environmental Science and Engineering: Ecology and Environmental studies. Khanna Publishers, New Delhi. Pp. 712.

[4] Kapoor A. (2001). Environmental microbiology: Environment and its important component, Alipur; Delhi.

[5] Keatinge W. R., Donaldson G. C., Cordioli E., Martinelli M., Kunst A. E., et al., BMJ 81 (2000) 795-800.

[6] Miller G. T., Spoolman S. (2008). Environmental science: Problekms, Concepts and Solutions. (12 ${ }^{\text {th }}$ Ed). Thompson Brooks/Cole, U.S.A. Pp. 584.

[7] Myers N., Tickell C. (2001). Cutting evolution down to our size. The Financial Times weekend supplement, October 27-28

[8] Myers S. S. (2009). Global Environmental Change: The Threat to Human Health. World watch Report 181.

[9] Narayanan P. (2009). Environmental pollution: Principles, Analysis and Control. CBS Publishers \& Distributors PVT.LTD. New Delhi, Pp. 671.

[10] Nwafor J. C. (2006). Environmental Impact Assessment for Sustainable Development: The Nigerian Perspective. El’DEMAK Publishers, Enugu. Pp. 1203.

[11] Taylor D. J, Green N. P. O., Stouts G. W. (2010). Biological Science 1\&2 (Editor: Soper, R) Cambridge University press U.K. Pp. 258 
[12] Weekly Trust (March 8, 2014). Climate Change: Who can save the World? Reported by Tina A. Hassan Page 58.S.

[13] L. U. Grema, A. B. Abubakar, O. O. Obiukwu, International Letters of Natural Sciences 3 (2013) 21-27.

[14] Hyginus A. Nwona, International Letters of Natural Sciences 4 (2013) 1-9. 